\title{
The role of nonhost cereal seeds in the epidemiology of cowpea bacterial blight (Xanthomonas axonopodis pv. vignicola (Burkholder) Dye)
}

\begin{abstract}
Cowpea (Vigna unguiculata (L) Walp.) production in Nigeria is mostly undertaken under mixed cropping systems with cereal crops. To determine the role of nonhost cereal seeds in the epidemiology of cowpea bacterial blight, farmer-saved maize, millet and sorghum seeds were collected from nine cowpea producing states and assessed for ability to harbor and transmit Xanthomonas axonopodis pv. vignicola. The pathogen was extracted consistently from millet seed samples from all the states, except Kebbi state at concentrations ranging from 0.2-3.3x102CFUmL-1. All maize and sorghum seed samples tested negative for the pathogen. By comparing direct seed plating, seed washing alone and seed blending pathogen extraction assays, it was found that pathogen extraction efficiency was significantly $(\mathrm{P}<0.05)$ enhanced when seeds were blended.

Emerging maize, sorghum, millet and cowpea seedlings harbored populations of the pathogen up to $3.3 \times 107 \mathrm{CFUmL}-1$ in the first week of seedling emergence. There was no significant variability in the pathogen population sizes on cowpea and nonhost seedlings, indicating that tissue colonization at this stage of growth was epiphytic. Pathogen population kinetics over a 49-day sampling period showed a gradual decline over time to levels that did not differ from those of untreated control in maize and sorghum. However, pathogen populations in millet tissues remained high on Day 49. Xanthomonas axonopodis pv. vignicola was transmitted systemically from inoculated cowpea, millet and sorghum (but not maize) seeds to seedlings, to harvested seeds at maturity. Susceptible cowpea plants grown together with the inoculated cereal crops were not cross-infected. The results of this study demonstrated that seeds of nonhost cereal crops could serve as passive reservoirs for Xanthomonas axonopodis pv. vignicola. Such epiphytic pathogen populations could serve as inoculum sources for bacterial blight in cowpea, leading to significant economic losses.
\end{abstract}

Keywords: xanthomonas axonopodis pv. Vignicola, cowpea; bacterial blight, nonhost plants, seeds, sorghum, millet, maize, Nigeria
Volume I Issue 5 - 2014

\author{
Simeon U Amodu, ' Abubakar D Akpa,' \\ Nnennaya O Agbenin,' Kenneth C Shenge',2 \\ 'Department of Crop Protection, Ahmadu Bello University, \\ Nigeria \\ ${ }^{2}$ The Ohio State University, OARDC Food Animal Health \\ Research Program, USA
}

Correspondence: Kenneth C Shenge, The Ohio State University, OARDC Food Animal Health Research Program, I 680 Madison Ave, Wooster, OH 4469I, USA, Tel + I (330) 263-3747, Fax + I (330) 263-3677, Email shenge. I@osu.edu

Received: November 14, 2014 | Published:December 0I, 2014

\section{Introduction}

Efficiency of transmission is an important requirement for pathogen fitness. ${ }^{1-3}$ In their quest for success, pathogens use plant seeds as an efficient means for dissemination and survival. ${ }^{3-5}$ Transmission through seeds occurs when pathogenic microorganisms successfully spread from infected or contaminated seeds to the emerging seedlings. Developing infected seedlings could become symptomatic within a few days or grow asymptomatically for variable periods of time. In addition, pathogens could survive perpetually in association with infected plants, spreading from seeds to plants and from plants to seeds without causing symptoms. ${ }^{5,6}$ Plant seeds could also harbor and disseminate a diverse microbial community that may include human pathogens like serovars of Salmonella enterica and Escherichia coli. ${ }^{7,8}$ Some human pathogens establish themselves endophytically in plants and may be inherited from one generation of its host to the next. ${ }^{9-11}$

On the behavior of seed-inhabiting bacterial plant pathogens during seed germination, Hirano et al., ${ }^{11}$ reported that Pseudomonas syringae pv. syringae did not behave like a parasite during bean seed germination, as its Hrp Type III secretion system (T3SS) did not seem to play a major role during seed germination and seedling colonization. According to Darrase et al., ${ }^{1}$ experiments to determine the efficiency of pathogen transmission from flowers to seeds, and from seeds to seedlings in incompatible, compatible and null pathogen-host combinations involving Xanthomonas campestris pv. campestrisbean, Xanthomonas campestris pv. citri-bean, and Escherichia colibean combinations, respectively, showed that bacterial population dynamics were similar in all three host-pathogen combinations, and that no defense responses were induced at seedling emergence. These results were similar to those of Dutta et al.m, ${ }^{4}$ who reported that Acidovorax citrulli, Clavibacter michiganensis subsp. michiganensis, Pseudomonas syringae pv. tomato, Xanthomonas euvesicatoria, and Pseudomonas syringae pv. glycinea were transmitted efficiently in compatible, incompatible and null combinations with watermelon, tomato, pepper and soybean plants. Collectively, these reports demonstrated that bacterial pathogens could be transmitted efficiently 
from flower-to-seeds, and from seeds to seedlings without associated defense response induction. ${ }^{1}$ The reported transmission of plantpathogenic bacteria to, from, and by nonhost seeds indicates that seeds of nonhost plants could be inoculum sources for important plant and human pathogens. ${ }^{1,12,13}$ In view of this possibility, and in consideration of the cropping systems in Northwestern Nigeria, where cowpea is often cultivated in mixed-cropping systems, the current study aimed at determining the possible role of nonhost cereal crops as a reservoir for the cowpea bacterial blight pathogen in Nigeria. A quantitative assessment of the traditional cropping systems revealed the existence of up to 43 crop mixtures in the Sudan savanna of Nigeria with a millet-cowpea mixture being predominant, representing $22 \%$ of the fields. ${ }^{14}$ Since plant seeds are reported to be colonized commensally by bacterial pathogens, ${ }^{1}$ the possibility of Xanthomonas campestris pv. vignicola being carried on the seeds of maize, sorghum, and millet was examined in this study. Seed borne bacterial pathogens are of major concern globally as strategies to manage bacterial disease are limited and often ineffective. ${ }^{3}$ Information on the transmission mechanisms of cowpea bacterial blight is critical to efforts aimed at developing effective strategies for controlling the disease.

\section{Materials and method}

\section{Collection of nonhost seeds}

Seeds of maize (Zea mays L.), sorghum (Sorghum bicolor L.) and foxtail millet (Setaria italic L.) were purchased from the open market in nine cowpea producing states in Nigeria. Three states were selected from each of North-Eastern, North-Central and North-Western Nigeria. In Borno state, seeds of the three crops were purchased from local farmers at Bama. Other locations where seeds were purchased were Akor (Gombe state), Mubi (Adamawa State), Duchin Kura (Sokoto State), Jega (Kebbi State), Saminaka (Kaduna State), Keffi (Nassarawa State), Mokwa (Niger State) and Idah (Kogi State). At each location, seeds of each crop weighing $2.5 \mathrm{~kg}$ were purchased from local farmers. The purchased seeds came from farmer-saved stocks and had no visible disease symptoms.

\section{Detection of Xanthomonas axonopodispv. vignicola on cereal grains}

The occurrence of Xanthomonas axonopodis pv. vignicola (Xav) on maize, sorghum and foxtail millet seeds was determined using seed washing, seed plating and seed destruction assays. ${ }^{8,15}$ For each crop, 400 seed-samples were drawn and washed thoroughly in running tap water to remove soil and debris. The washed seeds were surface-disinfected by soaking them in $2 \%$ sodium hypochlorite for three minutes, after which they were rinsed with sterile distilled water (SDW) and blended using a Philips blender model HR 2167/40 (Royal Philips, Amsterdam, The Netherlands). The paste was suspended in $250 \mathrm{~mL}$ of $0.85 \%$ sterile saline solution, from which serial dilutions up to $10^{-5}$ were prepared. From each dilution, $100 \mu \mathrm{L}$ were spread on two Petri-dishes containing Yeast Dextrose Carbonate Ager (YDCA) using a Drigalski spatula. ${ }^{16,17}$ The plates were there after incubated at $27^{\circ} \mathrm{C}$ for 7 days, after which colonies with typical Xav characteristics ${ }^{18}$ were enumerated and selected for pathogenicity testing.

Putative isolates were tested for their Gram reaction, and other biochemical tests, ${ }^{19,20}$ including Kovac's oxidase test, ${ }^{21}$ arginine dihydrolase, catalase activity, gelatin hydrolysis, starch hydrolysis and levan production. Putative bacterial pathogens were tested for induction of a hypersensitive reaction in tobacco leaves, ${ }^{22,23}$ and their pathogenicity confirmed by spaying suspensions of the pathogens (standardized at $107 \mathrm{CFU} / \mathrm{ml}$ ) on 35-day-old cowpea cv. Ife Brown.

\section{Washing assay for externally-borne pathogens}

The occurrence of Xav on the surfaces of maize, sorghum and millet seeds was determined by randomly selecting 400 seeds from each seed lot. The seeds were transferred into a $250 \mathrm{~mL}$ flask containing sterile distilled water (SDW) and shaken on an orbital shaker at 250 rpm for $5 \mathrm{~min}$, after which the rinsate was filtered through three layers of cheese cloth. The filtrate was dispensed into two 50-mL centrifuge tubes and centrifuge at $12,000 \mathrm{~g}$ for $10 \mathrm{~min}$ (approx. 10,000rpm) to pellet bacteria. One $\mathrm{ml}$ of the pelleted bacteria from each seed lot was transferred into McCartney bottles containing $9 \mathrm{ml}$ of SDW. From these, serial dilutions up to $10^{-5}$ were prepared in SDW, from which $10 \mu \mathrm{L}$ were spread on Petri-dishes containing YDCA using a Drigalski spatula. The treatments were incubated at $28^{\circ} \mathrm{C}$ for 7 days, after which colonies with typical $\mathrm{Xav}$ characteristics ${ }^{14}$ were enumerated and selected for pathogenicity testing.

\section{Direct seed plating assays}

Four hundred (400)seeds from each of cereal seed lots were washed with SDW, after which 10seeds were selected randomly and plated on YDCA in ten replicates. Seeds bearing Xav colonies growth were recorded as positive and those without $X a v$ growth were recorded as negative. Colonies that were mucoid, yellow, Gram-negative and hydrolyzed starch on YDCA were selected for pathogenecity testing. The trial was repeated twice.

Xanthomonas axonopodis pv. vignicola population kinetics in cowpea and cereal seedlings following seed inoculation

Four hundred (400) seeds from each of the cereal seed lots and cowpea (cv. Ife brown) were inoculated with Xav by soaking them in a suspension of the bacteria adjusted to ca. $4.5 \times 107 \mathrm{CFUmL}^{-1}$ for 4h. After $4 \mathrm{~h}$ of soaking, the bacteria suspension was drained out and three seeds from each treatment in a $25 \mathrm{~cm}$-diameter pot filled with heat sterilized soil. Emerging seedlings were watered as required and fertilized following fertilizer requirements for maize, sorghum, foxtail millet and cowpea. Seeds soaked in SDW for $4 \mathrm{~h}$ served as control. Leaf and stem discs measurin g ca. $2 \mathrm{~mm}^{2}$ were taken from the seedlings at $7,14,21,35$ and 49 days after inoculation, using a cork borer. The discs were teased apart in 1-2drops of SDW, from which a loop ful was transferred into $1 \mathrm{~mL}$ of SDW, from which serial dilutions up $10^{-5}$ were made and plated on YDCA. Emerging Xav colonies were enumerated after $48 \mathrm{~h}$. The experiments were laid out on a bench in the screen house using a completely randomized design with three replications. Data collected were analyzed statically using ANOVA models in MSTAT-C and treatment means separated using Student-Newman-Kuels (SNK) tests. The trials were repeated twice.

Transmission of Xanthomonas axonopodis pv. vignicola to nonhost seeds via vascular and floral systems

Direct infection of seeds by Xanthomonas axonopodis pv. vignicola through the vascular system: Direct systemic infection of seed by Xav was investigated using artificial inoculation methods, followed by grow-out assays and seed sampling. The cereal seeds were divided into 3 portions of 40 seeds each. One of the three portions was soaked in a Xav suspension adjusted to ca. $4.5 \times 107 \mathrm{CFU} / \mathrm{ml}-1$ before planting. The second portion of seeds was spray-inoculated with a bacterial suspension adjusted to ca. $4.7 \times 107 \mathrm{cfu} \mathrm{m}^{-1}$ at 25 days after sowing, 
while third portion was soaked in sterile distilled water and served as control. Three seeds from each of the three seed portions were planted in $25 \mathrm{~cm}$-diameter pots filled with sterilized soil. Emerging seedlings were thinned to two plants per pot after seedling establishment. After harvest, 100seeds from each treatment were placed on YDCA and emerging $\mathrm{Xav}$ colonies enumerated following incubation at $28^{\circ} \mathrm{C}$ for $48 \mathrm{~h}$. Another batch of three seeds from each treatment was planted in soil-filled pots in the screen house and tissue $2-\mathrm{mm}^{2}$ tissue samples from emerging seedlings assayed for the presence of Xav as described previously.

\section{Indirect systemic Xanthomonas axonopodis pv. vignicola infection via floral parts}

To determine indirect Xav systemic infection in the floral parts, cowpea plants inter-cropped with maize, sorghum and foxtail millet were sprayed with a bacterial suspensions adjusted to ca.4.5x107cfu/ $\mathrm{ml}$ at flowering stage using an atomizer. Cowpea pods were harvested at maturity and 100seeds each from cereal crops were placed on YDCA media. The seeds were also planted in the screen house and examined for the presence of Xav after seedling emergence using sampling and processing assays described previously.

\section{Results}

Xanthomonas axonopodis pv. vignicola was not detected on all the maize and sorghum seed sample. Results of detection assays for detection of Xav on millet seeds are summarized in Table 1. The results showed that efficiency of detection of the pathogen varied with detection assay used. Using washing assays, the pathogen was detected on millet seed samples from Gombe, Kaduna, Nassarawa, Kogi and Niger states at concentration levels ranging $1.0^{-1} .4 \times 102 \mathrm{CFU} /$ $\mathrm{mL}$. However, millet seeds from Borno, Adamawa, Sokoto and Kebbi were free of the pathogen. Apart from the millet sample from Gombe state (North-Eastern Nigeria), which tested positive for the pathogen, all the samples that tested positive came from states in North-Central Nigeria. With seed plating assays (Figure 1), Xav was detected on millet seed samples from Borno, Nassarawa, Kogi and Niger states, but not on seed samples from the other states. Seed destruction assays produced more consistent pathogen recovery from the seeds; all the millet sample (except those from Nassarawa State) tested positive for the pathogen, with recovered concentrations of the pathogen ranging from $0.2^{-3} .3 \times 102 \mathrm{CFU} / \mathrm{mL}$. All the nine putative Xav isolates of the pathogen recovered from positive millet samples tested positive for Xanthomonas axonopodis pv. vignicola on the basis of determinative biochemical, phenotypic, pathogenicity and hypersensitivity (HR on tobacco) tests (Table 2), (Table 3). Microscopic examination showed that the isolates possessed a unipolar flagellum. Isolates did not fluoresce under UV light; they were oxidase-negative, catalasepositive and positive for oxidative metabolism.

Results of in vivo Xav population dynamics on 7, 14 and 21 DAS showed that in vivo rhizosphere and phyllosphere populations of the pathogen in seedlings arising from treated seeds were significantly higher $(\mathrm{P}<0.05)$ than those in seedlings emerging from control plants, regardless of the host status of the crop and the plant part assayed (Table 4). At 35 and 49 DAS, in vivo assays recovered the pathogen from the leaves and stems of cowpea (cv. Ife Brown), and foxtail millet, but not in sorghum, maize and the untreated control (Table 5). Seed blending, seed washing and seed plating assays to determine direct vascular transmission and indirect transmission of Xav in non host seeds recovered the pathogen from millet seeds but not in maize seeds. However, inoculation of maize and millet floral systems resulted to transmission of the pathogen from the contaminated floral systems to seeds formed there from. Pathogen concentration in maize seeds was $2.0 \times 102 \mathrm{CFUmL}^{-1}$, while that in millet seeds, as detected using seed destruction and seed washing assays was $1.0 \times 102 \mathrm{CFUmL}^{-1}$ and $1.4 \times 103 \mathrm{CFUmL}^{-1}$, respectively (Table 6).
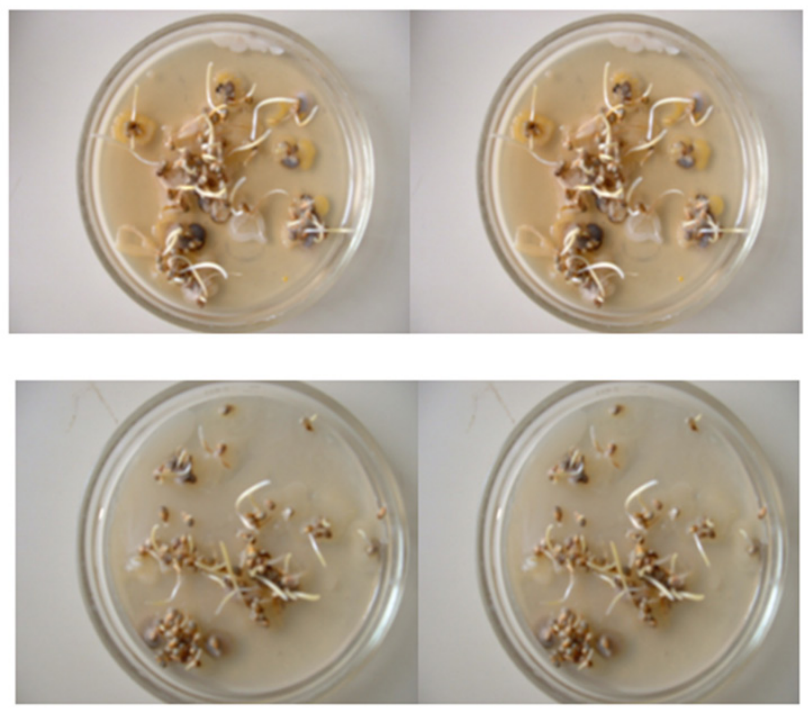

Figure I Growth of Xanthomonas axonopodis pv. vignicolacolonies on millet seeds in Yeast Dextrose Carbonate Agar (YDCA) plates. 
Table I Detection of Xanthomonas axonopodis vignicola from millet seeds in Nigeriał $\ddagger$ The pathogen was not detected on sorghum and maize seeds. $*+=X a v$. Detected; - =Xav. Not detected

\begin{tabular}{llll}
\hline Source & \multicolumn{2}{l}{ Pathogen extraction assay } & \\
\cline { 2 - 4 } & Seed washing $\left(\right.$ CFU $\left.\mathbf{~ L L}^{-1}\right)$ & Direct seed plating" & Plating blend seeds $\left(\mathrm{CFU} \mathbf{~ m L}^{-1}\right)$ \\
\hline Borno (Bama) & - & + & $0.2 \times 10^{2}$ \\
Gombe (Akor) & $1.0 \times 10^{2}$ & - & $1.3 \times 10^{2}$ \\
Adamawa (Mubi) & - & - & $1.0 \times 10^{2}$ \\
Sokoto (Duchin Kura) & - & - & $1.4 \times 10^{2}$ \\
Kaduna (Saminaka) & $1.2 \times 10^{2}$ & - & $3.3 \times 10^{2}$ \\
& - & - & - \\
Kebbi (Jega) & & & \\
Nasarawa (Keffi) & $1.1 \times 10^{2}$ & + & $1.2 \times 10^{2}$ \\
Kogi (Idah) & $1.0 \times 10^{2}$ & + & $2.4 \times 10^{2}$ \\
Niger (Mokwa) & $1.4 \times 10^{2}$ & + & $1.0 \times 10^{2}$ \\
\hline
\end{tabular}

Table 2 Morphological characteristics of Xanthomonas axonopodis vignicola isolates from millet seeds in Nigeria. *B, bright yellow; LY, light yellow; CY, creamy yellow $C$, extracellular polysaccharide $\dagger^{+}=$positive

\begin{tabular}{|c|c|c|c|c|}
\hline Source of isolates & Pigment color* & EPS $^{c, \uparrow}$ & Starch hydrolysis $^{\dagger}$ & Time of colony emergence (days) \\
\hline Borno (Bama) & B & + & + & 3 \\
\hline Gombe (Akor) & B & + & + & 3 \\
\hline Adamawa (Mubi) & B & + & + & 3 \\
\hline Sokoto (Duchinkura) & B & + & + & 4 \\
\hline Kaduna (Saminaka) & $\mathrm{CY}$ & + & + & 4 \\
\hline Kebbi (Jega) & B & + & + & 3 \\
\hline Kogi (Idah) & B & + & + & 3 \\
\hline Nassarawa (Keffi) & LY & + & + & 4 \\
\hline Niger (Mokwa) & $\mathrm{CY}$ & + & + & 4 \\
\hline
\end{tabular}

Table 3 Reaction of susceptible cowpea cultivars and tobacco plants to Xanthomonas axonopodis pv. vignicola isolates from millet seeds $+=$ Compatible/ positive reaction

\begin{tabular}{|c|c|c|c|c|c|}
\hline \multirow[b]{2}{*}{ Source of isolates } & \multicolumn{3}{|c|}{ Cowpea varieties } & \multirow[b]{2}{*}{$\begin{array}{l}\text { Hypersensitive reaction on } \\
\text { tobacco }\end{array}$} & \multirow{2}{*}{$\begin{array}{l}\text { Time of symptom } \\
\text { development } \\
\text { (Day) }\end{array}$} \\
\hline & IT86D-72I & SAMPEA-7 & Ife brown & & \\
\hline Borno (Bama) & + & + & + & + & $|5-2|$ \\
\hline Gombe (Akor) & + & + & + & + & $|5-2|$ \\
\hline Adamawa (Mubi) & + & + & + & + & $|2-2|$ \\
\hline Sokoto (Duchinkura) & + & + & + & + & $|0-2|$ \\
\hline Kaduna (Saminaka) & + & + & + & + & $|0-2|$ \\
\hline Kebbi (Jega) & + & + & + & + & $8-21$ \\
\hline Kogi (Idah) & + & + & + & + & $7-21$ \\
\hline Nassarawa (Keffi) & + & + & + & + & $7-21$ \\
\hline Niger (Mokwa) & + & + & + & + & $9-21$ \\
\hline
\end{tabular}

Citation: Amodu SU,Akpa AD, Agbenin NO, et al.The role of nonhost cereal seeds in the epidemiology of cowpea bacterial blight (Xanthomonas axonopodis pv. vignicola (Burkholder) Dye) . Adv Plants Agric Res. 2014; I (5): I99-205. DOI: I0.15406/apar.20 I4.01.0003 I 
Table 4 Concentration of Xanthomonas axonopodis pv. vignicola (CFU mL-I) in the rhizosphere and phyllosphere of cowpea, sorghum, maize and millet seedlings. Means in a column followed by the same letter are not significantly different at $\mathrm{P}<0.05$ by SNK test

\begin{tabular}{|c|c|c|c|c|c|c|}
\hline \multirow{3}{*}{ Treatment } & \multicolumn{6}{|c|}{ Sampling point (Days after sowing) } \\
\hline & \multicolumn{2}{|l|}{7} & \multicolumn{2}{|l|}{14} & \multicolumn{2}{|l|}{21} \\
\hline & Roots & Shoot & Root & Shoot & Root & Shoot \\
\hline Ife brown & $3.20 \times 10^{7} \mathrm{a}$ & $1.6 \times 10^{7} \mathrm{a}$ & $3.4 \times 10^{8} \mathrm{a}$ & $2.7 \times 10^{8} \mathrm{a}$ & $2.4 \times 10^{8} \mathrm{a}$ & $3.1 \times 10^{8} \mathrm{a}$ \\
\hline Samsorg-12 & $2.5 \times 10^{7} b$ & $1.0 \times 10^{7} \mathrm{c}$ & $2.2 \times 10^{7} a b$ & $1.2 \times 10^{7} \mathrm{~b}$ & $1.9 \times 10^{6} \mathrm{~b}$ & $1.0 \times 10^{6} \mathrm{c}$ \\
\hline Millet & $3.3 \times 10^{7} \mathrm{a}$ & $1.4 \times 10^{7} \mathrm{ab}$ & $3.2 \times 10^{7} \mathrm{~b}$ & $2.4 \times 10^{7} \mathrm{~b}$ & $2.2 \times 10^{6} \mathrm{ab}$ & $2.1 \times 10^{6} \mathrm{~b}$ \\
\hline Maize & $2.4 \times 10^{7} \mathrm{~b}$ & $1.3 \times 10^{7} \mathrm{~b}$ & $2.1 \times 10^{7} \mathrm{~b}$ & $1.1 \times 10^{7} \mathrm{~b}$ & $1.4 \times 10^{6} \mathrm{c}$ & $0.3 \times 10^{7 \mathrm{~d}}$ \\
\hline Ife brown & $0.00 c$ & $0.00 \mathrm{~d}$ & $0.00 c$ & $0.00 c$ & $0.00 \mathrm{~d}$ & $0.00 \mathrm{e}$ \\
\hline Millet control & $0.00 c$ & $0.00 \mathrm{~d}$ & $0.00 c$ & $0.00 c$ & $0.00 \mathrm{~d}$ & $0.00 \mathrm{e}$ \\
\hline
\end{tabular}

Table 5 Concentration of Xanthomonas axonopodis pv. vignicola (CFU mL-I) in leaf and stem tissues of older cowpea, sorghum, maize and millet seedlings. Means in a column followed by the same letter are not significantly different at $\mathrm{P}<0.05$ by SNK test

\begin{tabular}{lllll}
\hline \multirow{2}{*}{ Treatment } & \multicolumn{3}{l}{ Sampling point (Days after sowing) } \\
\cline { 2 - 5 } & 35 & \multicolumn{3}{c}{49} \\
\cline { 2 - 5 } & Leaves & Stem & Leaves & Stem \\
\hline Ife brown & $2.3 \times 10^{8} \mathrm{a}$ & $1.5 \times 10^{8} \mathrm{a}$ & $2.4 \times 10^{8} \mathrm{a}$ & $1.5 \times 10^{8} \mathrm{a}$ \\
Samsorg- 12 & $0.00 \mathrm{c}$ & $0.00 \mathrm{c}$ & $0.00 \mathrm{c}$ & $0.00 \mathrm{c}$ \\
Millet & $1.5 \times 10^{4} \mathrm{a}$ & $0.5 \times 10^{4} \mathrm{~b}$ & $1.2 \times 10^{4} \mathrm{~b}$ & $0.6 \times 10^{4} \mathrm{~b}$ \\
Maize & $0.00 \mathrm{c}$ & $0.00 \mathrm{c}$ & $0.00 \mathrm{c}$ & $0.00 \mathrm{c}$ \\
Ife brown & $0.00 \mathrm{c}$ & $0.00 \mathrm{c}$ & $0.00 \mathrm{c}$ & $0.00 \mathrm{c}$ \\
Millet control & $0.00 \mathrm{c}$ & $0.00 \mathrm{c}$ & $0.00 \mathrm{c}$ & $0.00 \mathrm{c}$
\end{tabular}

Table 6 Direct vascular and indirect floral transmission of Xanthomonas axonopodis pv. vignicola by non host cereal crops. $*+=$ Detected; - =Not detected

\begin{tabular}{|c|c|c|c|c|c|c|}
\hline \multirow[b]{2}{*}{ Treatment } & \multicolumn{3}{|c|}{ Direct vascular transmission* } & \multicolumn{3}{|c|}{ Indirect floral system transmission* } \\
\hline & $\begin{array}{l}\text { Plating blend seeds } \\
\left.\text { (CFU } \mathrm{mL}^{-1}\right)\end{array}$ & $\begin{array}{l}\text { Seed washing } \\
\text { (CFU mL-1) }\end{array}$ & $\begin{array}{l}\text { Direct seed } \\
\text { plating }\end{array}$ & $\begin{array}{l}\text { Plating blend seeds } \\
\left.\text { (CFU } \mathrm{mL}^{-1}\right)\end{array}$ & $\begin{array}{l}\text { Seed washing } \\
\left(C F U \mathrm{~mL}^{-1}\right)\end{array}$ & $\begin{array}{l}\text { Direct seed } \\
\text { plating }\end{array}$ \\
\hline Maize & - & - & - & $2.0 \times 10^{2}(\mathrm{cfu})$ & - & - \\
\hline Millet & $2.3 \times 10^{4}(\mathrm{cfu})$ & - & + & $1.0 \times 10^{3}(\mathrm{cfu})$ & $1.4 \times 10^{3}(\mathrm{cfu})$ & + \\
\hline
\end{tabular}

\section{Discussion}

The current study represents a systematic approach to examining the role of nonhost seeds in the transmission and epidemiology of the cowpea bacterial blight pathogen in Nigeria. The non-detection of Xanthomonas axonopodis pv. vignicola on maize and sorghum from all samples collected across the cowpea producing states in Nigeria indicated that seeds of these crops probably did not have a role in the transmission of $X a v$ from and to cowpea, and that they may therefore, not contributors to introduction of primary inoculums of cowpea bacterial blight to non-infested fields.

The results of this study demonstrated that efficiency of pathogen recovery from contaminated seeds can vary widely, depending on seed lot and extraction method employed. These findings were congruent with reports by Gitaitis et al. ${ }^{3,24}$ The finding in this study that selective media assays involving blending of the seeds were more sensitive than seed washing and direct seed plating assays were similar to those of Hadas et al., Fatimi and Schaad, ${ }^{24,25}$ who reported that blending tomato seeds for $10-15 \mathrm{~min}$ resulted in an increase in the extraction of Clavibacter michiganensis ssp. michiganensis from the seeds by $100 \%$ or more over washing for $72 \mathrm{hr}$. The inconsistency in detecting Xav on some of the millet seed samples could also be due to low incidence of the disease in the field of origin or stress imposed on the pathogen by seed treatment. ${ }^{26,27}$ Another reason could be that the bacteria were firmly attached to the seeds in biofilm, such that that washing assay could not dislodge them. ${ }^{26}$ Fett et al., ${ }^{28}$ reported that bacterial in biofilm are notoriously resistant to washing and other antibacterial treatments.

This study showed variations in the time it took Xav colonies to produce typical yellow pigmentation on YDCA media and disease 
symptoms on susceptible cowpea plants. These findings were in agreement with those of Alexander et al. ${ }^{15}$ Okechukwu et al. ${ }^{29}$ who also reported variability in the time it took Xanthomonas isolates to induce symptoms in susceptible hosts.

Bacterial population buildup at the early crop seedling stage is enabled by seed exudates released during seed germination. ${ }^{20,30,31}$ The finding of this study that Xav populations were significantly higher in the roots of cowpea and cereal seedlings at 7 DAS than in the shoot system were similar to those of Gilbertson et al., ${ }^{32}$ who reported that seed borne bacteria, especially xanthomonads colonized the surfaces of seedlings without an early endophytic development phase. The findings are also similar to those of Hirano et al., ${ }^{11}$ who reported that nutrients were not limiting factors in the bean spermosphere, enabling the rapid colonization of seedling surfaces. The steady decline in Xav populations observed in this study over time in all the cereal crops suggested a corresponding decline in nutrient availability for the bacteria during the exponential growth phase of the seedlings.

Seed infestation with plant pathogenic bacteria and subsequent transmission of pathogens by infected seeds has been reported..$^{3,33,34}$ However, the role of nonhost crop seeds in the epidemiology of plant bacterial diseases is not well understood. The finding in the current study that Xanthomonas axonopodis pv. vignicola was able to colonize the seeds of some nonhost crops, and to be transmitted systemically from floral systems of millet and sorghum to the developing seedling is in agreement with previous reports by Darasse et al., ${ }^{1}$ Dutta et al. ${ }^{4}$ and Darsonval et al., ${ }^{26}$ Similar observations were also reported by Dutta et al. ${ }^{4}$ However, this study also demonstrated that sorghum and millet plants arising from contaminated seeds were unable to serve as reservoirs of the pathogen, and to subsequently cross-contaminate cowpea plants with the pathogen when the crops were grown together.

\section{Conclusion}

This study demonstrated the asymptomatic colonization of nonhost cereal seeds by Xanthomonas axonopodis pv. vignicola. The study also showed that the pathogen was capable of being transmitted to the developing seeds of nonhost crops through direct vascular and floral pathways. Although these results point to the possibility that nonhost cereal crops could serve as passive reservoirs of the cowpea bacterial blight pathogen, their role in the epidemiology of the pathogen could not be established, since susceptible cowpea plants intercropped with pathogen-contaminated nonhost cereal crops were not cross-contaminated. However, epiphytic populations of the pathogen in cowpea fields could potentially infect cowpea crops and cause bacterial blight epidemics. These findings emphasize the need for cowpea bacterial management strategies under mixed cropping systems to apply the same preventative measure on the seeds of nonhost cereal crops as they do on cowpea seeds. The results of this study also demonstrated the need for cowpea seed certification standards in mixed cropping systems to take into account the possibility of nonhost seed borne inoculums of cowpea bacterial blight.

\section{Acknowledgements}

None.

\section{Conflict of interest}

The author declares no conflict of interest.

\section{References}

1. Darrasse A, Darsonval A, Boureau T, et al. Transmission of plant - pathogenic bacteria by nonhost seeds without induction of an associated defense reaction at emergence. Appl Environ Microbiol. 2010;76(20):6787-6796.

2. Fenton A, Fairbairn JP, Norman R, et al. Parasite transmission: reconciling theory and reality. Journal of Animal Ecology. 2002;71(5):893-905.

3. Gitaitis RD, Walcott RR. The epidemiology and management of seed borne bacterial diseases. Annu Rev Phytopathol. 2007;45:371-397.

4. Dutta B, Gitaitis R, Smith S, et al. Interactions of seed borne bacterial pathogens with host and non-host plants in relation to seed infestation and seedling transmission. Plos One. 2014;9(6):e99215.

5. Walcott RR. Detection of seed borne pathogens. Hort Technology. 2003;13(1):40-47.

6. Edreva A. Pathogenesis related proteins: Research progress in the last 15years. Gen Appl Plant Physiology. 2005;31(1-2):105-124.

7. Darsonval A, Darrasse A, Durand K, et al. Adhesion and fitness in the bean phyllosphere and transmission to seed of Xanthomonas fuscans subsp. fuscans. Mol Plant Microbe Interact. 2009;22(6):747-757.

8. $\mathrm{Hu} \mathrm{H}$, Churey JJ, Worobo KW. Heat treatments to enhance the safety of mung bean seeds. J Food Prot. 2004;67(6):1257-1260.

9. Cooley MB, Miller WG, Mandrell RE. Colonization of Arabidopsis thaliana with Salmonella enterica and enterohemorrhagic Escherichia coli O157:H7 and competition by Enterobacter asburiae. Appl Environ Microbiol. 2003;69(8):4915-4926.

10. Deering AJ, Pruitt RE, Mauer LJ, et al. Examination of the internalization of Salmonella serovar Typhimurium in peanut, Arachis hypogaea, using immunocytochemical techniques. Food Research International. 2012;45(2):1037-1043.

11. Hirano SS, Charkowski A, Colimer A, et al. Role of the Hrp type III protein secretion system in growth of Pseudomonas syringae pv.syringaeB728a on boat plants in the field. Proc Natl Acad Sci USA. 1999;96(17):98519856.

12. Darsonval A, Darrasse A, Meyer D, et al. Type III secretion system of Xanthomonas fuscans subsp. fuscans is involved in the phyllosphere colonization process and in transmission to seeds of susceptible beans. Appl Environ Microbiol. 2008;4(9):2669-2678.

13. Schaad NW, Dianese JC. Cruciferous weeds as sources of inoculum of Xanthomonas campestris in black rot of crucifers. Phytopathology. 1981;71:1215-1220.

14. Henriet JGA, Van EK, Blalle SF, et al. Quantitative assessment of traditional cropping system in the Sudan Savanna of northern Nigeria. Rapid survey of prevalent cropping systems. Samaru Journal of Agricultural Research. 1997;14:37-45.

15. Alexander MB, Mabagala RB, Guzman P, et al. Genetic diversity and pathogenic variation of common blight bacteria (Xanthomonas campestris pv. phaseoliand X. campestris pv. phaseolivar. fuscans) suggests pathogen coevolution with the common bean. Phytopathology. 2004;94(6):593- 603

16. Chiarappa L. Worldwide losses due to seed-borne diseases. In: Mathur SB, et al. editors. Seed Pathology. Danish Technical Centre for Agricultural and Rural Co-operation; 1988. p. 17-27.

17. Mortensen CN. Seed Health Testing for Bacterial Pathogens. Danish Government Institute of Seed pathology for Developing countries (DGISP) Copenhagen Denmark; 1977. 66 p. 
18. Holt JG, Krieg NR, Sneath PHA, et al. Bergey's manual of determinative bacteriology. 9th ed. USA: Lippincott Williams \& Wilkins; 1994. 816 p.

19. Lelliott RA, Stead DE. Methods for the diagnosis of bacterial diseases of plants. In: Preece TF editor. Methods in Plant Pathology. (Vol. II), Blackwell Scientific Publications, Oxford; 1987. 216 p.

20. Schaad NW, Jones JB, Chun W. Laboratory guide for identification of plant pathogenic bacteria. 3rd ed. St. Paul, Minnesota, USA: American Phytopathological Society Press; 2001. 398 p.

21. Kovacs N. Identification of Pseudomonas pyocyanea by the oxidase reaction. Nature. 1956;178(4535):703.

22. Agrios GN. Plant Pathology. 5th ed. Burlington, MA, USA: Elsevier Academic Press; 2005. 948 p.

23. Goodman RN, Novacky AJ. The Hypersensitive reaction in plants to pathogens. A resistance phenomenon. Saint Paul, Minnesota, USA: APS Press; 1994. 256 p.

24. Hadas R, Kritzman G, Klietman F, et al. Comparison of extraction procedures and determination of the detection threshold for Clavibacter michiganensis ssp. michiganensis in tomato seeds. Plant Pathology. 2005;54(5):643-649.

25. Fatmi M, Schaad NW. Semiselective agar medium for isolation of Clavibacter michiganense subsp. michiganense from tomato seed. Phytopathology. 1988;78(1):121-126.

26. Darsonval A, Darrasse A, Durand K, et al. Adhesion and fitness in the bean phyllosphere and transmission to seed of Xanthomonas fuscans subsp. Fuscans. Mol Plant Microbe Interact. 2009;22(6):747-757.
27. Lioa $\mathrm{CH}$, Shollenberger LM. Enumeration, resuscitation and infectivity of sub lethally injured Erwinia cells induced by mild acid treatment. Phytopathology. 2004;94(1):76-81.

28. Fett WF, Cook PH. A survey of native microbial aggregates on alfalfa, clover and mung bean sprout cotyledons for thickness as determined by confocal scanning laser microscopy. Food Microbiology. 2005;22(23):253-259.

29. Okechukwu RU, Ekpo EJA, Florini DA. Yield depression in cowpea cultivars infected with Xanthomonas campestris pv. vignicola in Sudan Savanna of Nigeria. Tropical Agricultural Research and Extension. 2000;3(2):98-101.

30. Rane KK, Latin RX. Bacterial fruit blotch of watermelon: Association of the pathogen with seed. Plant Disease. 1992;76(5):509-512.

31. Schaad NW, Sowell G, Goth RW, et al. Pseudomonas pseudoalcaligenes subsp. Citrulli subsp. nov. International Journal of Systematic Bacteriology. 1978;28(1):117-125.

32. Gilberston RL, Maxwell DP. Common bacterial blight of bean. In: Chaube HS, et al. editors. Diseases of international importance. (Vol. 2), Englewood Cliffs, New Jersey, USA: Prentice Hull; 1992. p. 18-39.

33. Dutta B, Avci U, Hahn MG, et al. Location of Acidovoraxcitrulliin infested watermelon seeds is influenced by the pathway of bacterial ingress. Phytopathology. 2012;102(5):461-468.

34. Dutta B, Block CC, Stevenson KL, et al. Distribution of Phytopathogenic bacteria in infested seeds. Seed Science and Technology. 2013;41(3):383397. 